\title{
Plant Maturity Affects Flowering Ability and Flower Quality in Phalaenopsis, Focusing on Their Relationship to Carbon-to-nitrogen Ratio
}

\author{
Shing-Shan Tsai and Yao-Chien Alex Chang \\ Department of Horticulture and Landscape Architecture, National Taiwan \\ University, Taipei 10617, Taiwan
}

Additional index words. $\mathrm{C} / \mathrm{N}$ ratio, juvenility, orchid, plant age, tissue analysis

Abstract. In the commercial production of phalaenopsis orchids, the cultivation time after deflasking is used to describe the plant age and maturity. Carbon-to-nitrogen $(\mathrm{C} / \mathrm{N})$ ratio is often used as an indicator of plant growth and flowering potential. High $\mathrm{C} / \mathrm{N}$ ratios are considered to promote reproductive growth, and low $\mathrm{C} / \mathrm{N}$ ratios are associated with the early vegetative growth or even inhibiting flowering. This study investigated how plant age and maturity affected flowering ability and flower quality of phalaenopsis and their relationship to $\mathrm{C} / \mathrm{N}$ ratio. The plant materials of various ages were the purple, small-flowered Phalaenopsis Sogo Lotte 'F2510' and white, large-flowered $P$. Sogo Yukidian 'V3', which were 2 to 7 months and 10 to 20 months after deflasking, respectively. Plants were placed under $25 / 20{ }^{\circ} \mathrm{C}$ for 4 months to force flowering and investigate the flowering-related parameters. The leaf $\mathrm{C} / \mathrm{N}$ ratio of both varieties increased in general with the increase of plant age. The spiking (flower-stalk emergence) rate of $\boldsymbol{P}$. Sogo Lotte 'F2510' 2 months after deflasking was only $42 \%$, which indicates that these plants were not completely out of their juvenile phase, whereas that of those 3 to 7 months after deflasking was $100 \%$, indicating that plants had acquired full flowering ability. No linear correlation was found between the $C / N$ ratio and days to spiking, to first visible bud, to first flower open, and to $\mathbf{9 0 \%}$ flower opening in the white, large-flowered $P$. Sogo Yukidian 'V3'. However, there was a positive correlation between the $\mathrm{C} / \mathrm{N}$ ratio and inflorescence length, flower-stalk diameter, first flower diameter, and flower count. Thus, the $\mathrm{C} / \mathrm{N}$ ratio is feasible to be used as an indicator for assessing the flowering quality in phalaenopsis.

Both woody and perennial herbaceous seedlings have a juvenile phase of various lengths in their lifecycle. During this phase, even when plants are provided with favorable conditions for flowering or treated with horticultural methods, flower initiation cannot be induced. Therefore, the juvenile phase is defined as a stage in which plants do not have the ability of sexual reproduction, and when plants are able to react to environmental or artificial stimuli for flowering, it is the end of the juvenile phase (Schwabe, 1975).

Received for publication 1 Oct. 2021. Accepted for publication 18 Oct. 2021.

Published online 5 January 2022.

This study is a part of the thesis submitted by S.-S. Tsai in partial fulfillment of master of science degree requirements. We thank Yin-Tung Wang, Chia-Nan Tao, and Hadi Susilo for their constructive comments on the manuscript. Financial support was provided by the Agriculture and Food Agency, Council of Agriculture, Taiwan (105AS9.6.1-FD-Z1; 106AS-8.5.3-FD-Z1; 107AS-7.5.3FD-Z1).

Y.-C.A.C. is the corresponding author. E-mail: alexchang@ntu.edu.tw.

This is an open access article distributed under the CC BY-NC-ND license (https://creativecommons. org/licenses/by-nc-nd/4.0/). number, leaf area, and plant size, allowing plants to accumulate abundant nutrients for advancing toward the end of their juvenile phase (Lee, 1991). Thus, it may be possible to use leaf number, leaf area, or $\mathrm{C} / \mathrm{N}$ ratio as an indicator of maturity in Phalaenopsis.

$\mathrm{C} / \mathrm{N}$ ratio is often used as an indicator of plant growth and flowering potential. High $\mathrm{C} /$ $\mathrm{N}$ ratios are considered to promote reproductive growth, and low $\mathrm{C} / \mathrm{N}$ ratios are associated with vegetative growth or even inhibit flowering. The nitrogen concentrations in the white, large-flowered Phalaenopsis Sogo Yukidian 'V3' and the purple, small-flowered $P$. Sogo Lotte 'F2510' decreased gradually and $\mathrm{C} / \mathrm{N}$ ratio increased as their vegetative growth advances. However, during the reproductive stage, the nitrogen concentration and $\mathrm{C} / \mathrm{N}$ ratio of $P$. Sogo Yukidian 'V3' maintained constant, whereas the nitrogen concentration and $\mathrm{C} / \mathrm{N}$ ratio of the purple, smallflowered $P$. Sogo Lotte 'F2510' continued the same trends as those in its vegetative stage (Lin and Chang, 2017).

Previous studies have shown that $\mathrm{C} / \mathrm{N}$ ratio may be a critical factor for the transition from the juvenile to reproductive maturity. A single long day treatment was applied to Arabidopsis thaliana and Sinapis alba for inducing flowering and the $\mathrm{C} / \mathrm{N}$ ratio of leaf exudates in both species increased dramatically in the early stage of treatment (Corbesier et al., 2002). Potassium chlorate application can induce flowering in longan (Dimocarpus longan). Wangsin and Pankasemsuk (2005) treated longan trees with various concentrations of potassium chlorate and compared the total nitrogen, total nonstructural carbohydrate, and $\mathrm{C} / \mathrm{N}$ ratio among treatments. When potassium chlorate-treated trees started flowering, total nitrogen, $\mathrm{C} / \mathrm{N}$ ratio, and especially total nonstructural carbohydrate of these longan stems were higher than those in the untreated trees. Litchi (Litchi chinensis Sonn. cv. Bombai) plants treated with $2 \mathrm{~mL} \cdot \mathrm{L}^{-1}$ Ethrel had the highest percentage of flowering shoots, and $\mathrm{C} / \mathrm{N}$ ratios of leaf and stem on these trees were also the highest (Mandal et al., 2014).

Flower initiation and development are affected by many factors, such as juvenility, temperature, photoperiod, and plant hormone. In addition, plant nutrient status can also

Fig. 1. The carbon/nitrogen $(\mathrm{C} / \mathrm{N})$ ratio of Phalaenopsis Sogo Lotte 'F2510' at various plant ages. Vertical bars indicate SE of 12 replications. Means with different letters are significantly different by the least significant difference test at $P \leq 0.05 ; \mathrm{n}=12$.

Orchids are perennial herbaceous plants, species and cultivars (Lee, 1991). For example, the duration of the juvenile phase in Spa11 months but, in Aranda Lucy Laycock, it can be 13 years and 3 months (Hew and Yong, 2004). In commercial production, Phalaenopsis plants are supplied with optinutrients and favorable growth tions, which lead to a quick increase in leaf

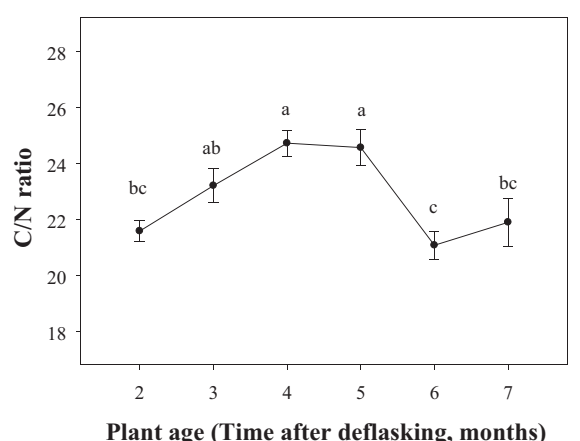

Plant age (Time after deflasking, months) 
influence flower initiation and development. When a plant switches its growth from vegetative to reproductive, the sink and source relationship among plant organs is also altered, which leads to changes in nutrient transport and $\mathrm{C} / \mathrm{N}$ ratio in the plant. Most studies examined the $\mathrm{C} / \mathrm{N}$ ratio in fruit trees and little attention has been devoted to studying the $\mathrm{C} / \mathrm{N}$ ratio in orchids. Thus, the purple, small-flowered $P$. Sogo Lotte 'F2510' and the white, large-flowered $P$. Sogo Yukidian 'V3' of various ages were used to investigate the $\mathrm{C} / \mathrm{N}$ ratio of the second acropetal leaf. For the purple, small-flowered $P$. Sogo Lotte 'F2510', plant age was used as an indicator of maturity, and the relationship between flowering ability and plant age was studied. We used the white, large-flowered $P$. Sogo Yukidian 'V3' to examine the relationship between leaf $\mathrm{C} / \mathrm{N}$ ratio and flower quality, as well as for the potential of using $\mathrm{C} / \mathrm{N}$ ratio as an indicator of reproductive maturity.

\section{Materials and Methods}

Plant materials and growing conditions. Phalaenopsis Sogo Lotte 'F2510' plants (producing small purple flowers), aged at 2 to 7 months after deflasking (referred to as plant age hereafter), were bought all at once from SOGO by Dümmen Orange (Kaohsiung, Taiwan). Phalaenopsis Sogo Yukidian 'V3' plants (producing large white flowers), 10 to 20 months after deflasking, were purchased together from Oriental Star Orchids Group (Chiayi, Taiwan). Tightly packed sphagnum moss was used as the sole growing medium. The 'F2510' plants were grown in $4.5-\mathrm{cm}$ soft plastic pots, whereas the 'V3' plants aged 10 to 11 months were grown in $7.5-\mathrm{cm}$ soft plastic pots and in $10.5-\mathrm{cm}$ pots for the 12- to 20-month plants.

These plants were then placed in a $30 /$ $25^{\circ} \mathrm{C}$ (day/night) growth chamber for $3 \mathrm{~d}$ to recover. The photoperiod and average photosynthetic photon flux $(P P F)$ in the growth chamber were $12 \mathrm{~h}$ and $28.9 \mu \mathrm{mol} \cdot \mathrm{m}^{-2} \cdot \mathrm{s}^{-1}$, respectively. After recovering, plants were transferred to a $25 / 20^{\circ} \mathrm{C}$ phytotron for forcing until the end of experiment. The average $P P F$ for $P$. Sogo Lotte 'F2510' and $P$. Sogo Yukidian 'V3' was 112 and 103 $\mu \mathrm{mol} \cdot \mathrm{m}^{-2} \cdot \mathrm{s}^{-1}$, respectively. Plants were fertigated with a water-soluble Peters Professional 20-20-20 (20N-8.6P-16.6K) fertilizer (Everris NA, Dublin, $\mathrm{OH}$ ) at $50 \mathrm{mg} \cdot \mathrm{L}^{-1} \mathrm{~N}$ every 1 to 2 weeks. $P$. Sogo Lotte 'F2510'

Table 1. Flowering parameters of Phalaenopsis Sogo Lotte 'F2510' as affected by plant age.

\begin{tabular}{lcccc}
\hline $\begin{array}{l}\text { Plant age } \\
(\text { mo. })^{\mathrm{z}}\end{array}$ & $\begin{array}{c}\text { Time to spiking } \\
(\mathrm{d})\end{array}$ & $\begin{array}{c}\text { Time to visible } \\
\text { bud }(\mathrm{d})\end{array}$ & $\begin{array}{c}\text { Time to first flower } \\
\text { open }(\mathrm{d})\end{array}$ & $\begin{array}{c}\text { Time to } 90 \% \text { flower } \\
\text { open }(\mathrm{d})\end{array}$ \\
\hline 2 & $50.2 \mathrm{a}^{\mathrm{y}}$ & $89.2 \mathrm{a}$ & $116.0 \mathrm{a}$ & $140.2 \mathrm{~b}$ \\
3 & $34.3 \mathrm{~b}$ & $75.1 \mathrm{~b}$ & $104.6 \mathrm{~b}$ & $151.9 \mathrm{ab}$ \\
4 & $30.3 \mathrm{c}$ & $69.2 \mathrm{~cd}$ & $100.8 \mathrm{c}$ & $160.8 \mathrm{a}$ \\
5 & $29.7 \mathrm{c}$ & $71.1 \mathrm{c}$ & $100.7 \mathrm{c}$ & $157.2 \mathrm{ab}$ \\
6 & $30.6 \mathrm{c}$ & $70.0 \mathrm{~cd}$ & $100.5 \mathrm{c}$ & $148.7 \mathrm{ab}$ \\
7 & $29.6 \mathrm{c}$ & $67.3 \mathrm{~d}$ & $98.9 \mathrm{c}$ & $151.8 \mathrm{ab}$ \\
\hline
\end{tabular}

${ }^{\mathrm{z}}$ Months after deflasking.

${ }^{\mathrm{y}}$ Means with different letters are significantly different by the least significant difference test at $P \leq$ $0.05 ; \mathrm{n}=12$.

and $P$. Sogo Yukidian 'V3' each had 12 and 4 replicates, respectively, for each plant age.

Analysis of leaf carbon and nitrogen. Leaf tissue carbon and nitrogen were analyzed as described previously (Lin, 2017). Briefly, parts of the second acropetal leaves were collected from each plant for analyzing carbon and nitrogen concentrations. Samples were dried at $70^{\circ} \mathrm{C}$ and then homogenized with a 150-g high-speed grinder (RT-02; Rong Tsong Precision Technology, Taiwan) or a tissue grinder (SH-100; Kurabo Industries LTD., Japan). Carbon and nitrogen concentrations of each sample were determined by an NC Analyzer (Flash EA 1112 Series; Thermo Fisher Scientific, Rodano, Milan, Italy) following the technical manual from the manufacturer. Powdered plant tissue between 2.5 and $3.5 \mathrm{mg}$ from each sample was embedded in an $8 \times 5$-mm tin capsule (Elemental Microanalysis, Okehampton, $\mathrm{UK})$, then injected into the machine. Atropine $\left(\mathrm{C}_{17} \mathrm{H}_{23} \mathrm{NO}_{3} ;\right.$ Fisons Instruments S.p.A., Rodano, Milano, Italy) was used as a reference standard for drawing the standard curve.

Measurements and statistical analysis. Spiking rate, days to spiking (when the potentially flowering stem reaching $0.5 \mathrm{~cm}$ in length), days to visible bud (when the length of the first flower bud was $\approx 0.5 \mathrm{~cm}$ ), days to first flower open and $90 \%$ flower opening, inflorescence length (at full bloom), flowerstalk diameter, first flower diameter, and flower count were recorded in both $P$. Sogo Lotte 'F2510' and $P$. Sogo Yukidian 'V3' plants. For the purple, small-flowered $P$. Sogo Lotte 'F2510', we also documented the percentage of plants with multiple flower stalks and node of flower-stalk emergence.

The study was conducted in a completely randomized design. Mean separation was carried out by the least significant difference test at $P \leq 0.05$. Costat (Version 6.1; CoHort
Software, Monterey, CA) was used for statistical analysis. SigmaPlot software (Version 10.0; Systat Software, San Jose, CA) was used for simple linear regression analysis and plotting figures.

\section{Results}

Expt. 1. Effects of plant maturity on $C / N$ ratio, flowering ability, and flower quality. The leaf $\mathrm{C} / \mathrm{N}$ ratio of the purple, small-flowered $P$. Sogo Lotte 'F2510' increased with plant age up to 5 months and then declined (Fig. 1). The $\mathrm{C} / \mathrm{N}$ ratio at 2 months after deflasking was 21.7 that increased to 24.6 at 5 months after deflasking. Nevertheless, the $\mathrm{C} / \mathrm{N}$ ratio dropped to 21.1 and 21.9 in 6- and 7-month old plants, respectively (Fig. 1)

Time to spiking became shorter as plant age increased (Table 1). After forcing at 25/ $20^{\circ} \mathrm{C}$, days to spiking was 50.2 for the 2 month-old plants, whereas it only took $34.3 \mathrm{~d}$ for the 3-month-old plants to reach spiking. There was no further difference in time to spiking for the older plants, which was between 29.6 and $30.6 \mathrm{~d}$.

A similar trend was seen in time to visible buds (Table 1). The earliest flower buds were seen in 7-month-old plants and the last in 2month-old plants. It took $89.2 \mathrm{~d}$ for the 2month-old plants to reach visible buds, and the time decreased to $75.1 \mathrm{~d}$ and $67.3 \mathrm{~d}$ in 3and 7-month-old plants, respectively (Table 1).

The time needed to reach first flower open (anthesis) in $P$. Sogo Lotte 'F2510' decreased with increasing plant age (Table 1). The time to reach anthesis was $116 \mathrm{~d}$ in 2-month-old plants but was $104.6 \mathrm{~d}$ in 3-month-old plants. There was no statistical difference in days to first flower open in 4- to 7-month-old plants, which was between 98.9 and $100.8 \mathrm{~d}$ (Table 1). It took the 2-month-old plants $140.2 \mathrm{~d}$ to

Table 2. Effect of plant age on flower quality of Phalaenopsis Sogo Lotte 'F2510'.

\begin{tabular}{|c|c|c|c|c|c|c|c|}
\hline $\begin{array}{l}\text { Plant age } \\
(\mathrm{mo.})^{\mathrm{z}}\end{array}$ & $\begin{array}{c}\text { Flower-stalk } \\
\text { emergence } \\
(\%)\end{array}$ & $\begin{array}{c}\text { Double stalk } \\
(\%)\end{array}$ & $\begin{array}{l}\text { Node no. of } \\
\text { flower-stalk } \\
\text { emergence }\end{array}$ & $\begin{array}{l}\text { Inflorescence } \\
\text { length }(\mathrm{cm})\end{array}$ & Flower-stalk diam (mm) & $\begin{array}{l}\text { First flower } \\
\text { diam }(\mathrm{mm})\end{array}$ & $\begin{array}{c}\text { Flower } \\
\text { count (no.) }\end{array}$ \\
\hline 2 & $42 \%$ & $0 \%$ & $4.4 \mathrm{c}^{\mathrm{y}}$ & $13.2 \mathrm{~d}$ & $3.4 \mathrm{c}$ & $43.9 \mathrm{a}$ & $4.6 \mathrm{~d}$ \\
\hline 3 & $100 \%$ & $8 \%$ & $5.4 \mathrm{ab}$ & $15.0 \mathrm{c}$ & $3.8 \mathrm{c}$ & $39.4 \mathrm{~b}$ & $6.8 \mathrm{c}$ \\
\hline 4 & $100 \%$ & $0 \%$ & $5.2 \mathrm{ab}$ & $17.3 \mathrm{~b}$ & $4.6 \mathrm{ab}$ & $41.4 \mathrm{ab}$ & $7.9 \mathrm{~b}$ \\
\hline 5 & $100 \%$ & $0 \%$ & $5.3 \mathrm{ab}$ & $16.9 \mathrm{~b}$ & $4.4 \mathrm{ab}$ & $42.1 \mathrm{a}$ & $6.9 \mathrm{bc}$ \\
\hline 6 & $100 \%$ & $33 \%$ & $5.4 \mathrm{a}$ & $17.4 \mathrm{~b}$ & $4.3 \mathrm{~b}$ & $41.6 \mathrm{ab}$ & $9.8 \mathrm{a}$ \\
\hline 7 & $100 \%$ & $8 \%$ & $5.0 \mathrm{~b}$ & $18.9 \mathrm{a}$ & $4.7 \mathrm{a}$ & $43.5 \mathrm{a}$ & $9.4 \mathrm{a}$ \\
\hline
\end{tabular}

${ }^{\mathrm{z}}$ Months after deflasking.

${ }^{\mathrm{y}}$ Means with different letters were significantly different by the least significant difference test at $P \leq 0.05 ; \mathrm{n}=12$. 
reach the stage of $90 \%$ flower open; however, 148.7 to $160.8 \mathrm{~d}$ was needed for the 3- to 7month-old plants to reach this stage.

Only $42 \%$ of the 2 -month-old plants flowered, whereas $100 \%$ of the 3- to 7-month-old plants produced flowers (Table 2). Plants had the highest rate of double stalk at $33 \%$ when forced at 6 months after deflasking (Table 2). As for flower-stalk emergence node, the stalk of 2-month-old plants emerged from the fourth or fifth node from the top, whereas for the 3- to 7-month-old plants, the stalk came out of the fifth or sixth node (Table 2).

Both inflorescence length and stalk diameter of $P$. Sogo Lotte 'F2510' increased as plant age progressed (Table 2). The inflorescence length was $13.2 \mathrm{~cm}$ and stalk diameter was $3.4 \mathrm{~mm}$ in 2-month-old plants. The 7month-old plants had the longest inflorescence and largest stalk diameter, which was $18.9 \mathrm{~cm}$ and $4.7 \mathrm{~mm}$, respectively. The flower count progressively increased as plants were more advanced in age, from 4.6 to nearly 10 on 2- and 6-month-old plants, respectively (Table 2 ).

Expt. 2. The relationship among plant maturity, $\mathrm{C} / \mathrm{N}$ ratio, and flower quality. From 10 to 20 months after deflasking, the $\mathrm{C} / \mathrm{N}$ ratio of $P$. Sogo Yukidian 'V3' plants increased with plant age or maturity (Table 3, Fig. 2). The lowest $\mathrm{C} / \mathrm{N}$ ratio of 20.5 was in the 10-month-old plants. Twenty months after deflasking, plants had the highest $\mathrm{C} / \mathrm{N}$ ratio of 27.3 (Table 3 ).

Plant $\mathrm{C} / \mathrm{N}$ ratio is affected by carbon and nitrogen concentrations. Ten months after deflasking, phalaenopsis ' $\mathrm{V} 3$ ' plants had a higher level of nitrogen concentration at $2.09 \%$, whereas the lowest nitrogen concentration of $1.61 \%$ was detected in the 20 month-old plants (Table 3). The carbon concentration did not vary much, ranging from $42.5 \%$ to $43.8 \%$. Owing to the declining $\mathrm{N}$ and a relatively stable $\mathrm{C}$ level as plant aged, there was a negative linear relationship between nitrogen concentration and $\mathrm{C} / \mathrm{N}$ ratio ( $r=0.98, P<0.001)$, but no relationship existed between carbon concentration and $\mathrm{C} /$ $\mathrm{N}$ ratio in $P$. Sogo Yukidian 'V3' $(P=0.23$; Fig. 3).

After forcing at $25 / 20^{\circ} \mathrm{C}$, the 10 - to 15 month-old phalaenopsis 'V3' started to spike between 31.0 and $43.5 \mathrm{~d}$, and visible flower bud and first flower opening was between 79.3 to $89.8 \mathrm{~d}$ and 106.5 to $119.3 \mathrm{~d}$, respectively (Table 4). For the 16- to 20-month-old plants, time to spiking was between 25.5 and $29.5 \mathrm{~d}$, and time to visible bud was between 72.0 and $76.8 \mathrm{~d}$, faster than those in the younger plants. Furthermore, these plants reached anthesis between 102.5 and $105.5 \mathrm{~d}$ after forcing began (Table 4). It took 137.5 and $133.3 \mathrm{~d}$ for the 10- and 11-month-old phalaenopsis 'V3', respectively, to reach $90 \%$ flower opening that were slightly shorter than plants of other ages. For the 20-month-old plants, $149.0 \mathrm{~d}$ were required to reach $90 \%$ flower opening (Table 4). There was no relationship between leaf $\mathrm{C} / \mathrm{N}$ ratio and time to spiking, visible bud, first flower opening, and 90\% flower opening (Fig. 4).

Table 3. Change of nitrogen concentration, carbon concentration, and carbon/nitrogen ratio of Phalaenopsis Sogo Yukidian 'V3' at various plant ages.

\begin{tabular}{lccl}
\hline Plant age (mo.) & Nitrogen concn $(\% \mathrm{DW})$ & Carbon concn $(\% \mathrm{DW})$ & $\mathrm{C} / \mathrm{N}$ ratio \\
\hline 10 & $2.09 \mathrm{a}^{\mathrm{y}}$ & $42.7 \mathrm{~cd}$ & $20.5 \mathrm{e}$ \\
11 & $1.75 \mathrm{cde}$ & $42.7 \mathrm{~cd}$ & $24.5 \mathrm{bc}$ \\
12 & $1.75 \mathrm{cde}$ & $43.0 \mathrm{abcd}$ & $24.6 \mathrm{bc}$ \\
13 & $1.96 \mathrm{abc}$ & $42.9 \mathrm{bcd}$ & $21.9 \mathrm{de}$ \\
14 & $1.95 \mathrm{abc}$ & $42.5 \mathrm{~d}$ & $21.9 \mathrm{de}$ \\
15 & $2.10 \mathrm{a}$ & $43.1 \mathrm{abcd}$ & $20.8 \mathrm{e}$ \\
16 & $1.93 \mathrm{abc}$ & $43.6 \mathrm{ab}$ & $22.6 \mathrm{cde}$ \\
17 & $2.06 \mathrm{ab}$ & $43.4 \mathrm{abc}$ & $21.3 \mathrm{e}$ \\
18 & $1.84 \mathrm{bcd}$ & $43.8 \mathrm{a}$ & $23.9 \mathrm{bcd}$ \\
19 & $1.68 \mathrm{de}$ & $43.6 \mathrm{ab}$ & $26.1 \mathrm{ab}$ \\
20 & $1.61 \mathrm{e}$ & $43.7 \mathrm{ab}$ & $27.3 \mathrm{a}$ \\
\hline
\end{tabular}

${ }^{\mathrm{z}}$ Months after deflasking.

${ }^{\mathrm{y}}$ Means with different letters were significantly different by the least significant difference test at $P \leq$ $0.05 ; \mathrm{n}=4$.

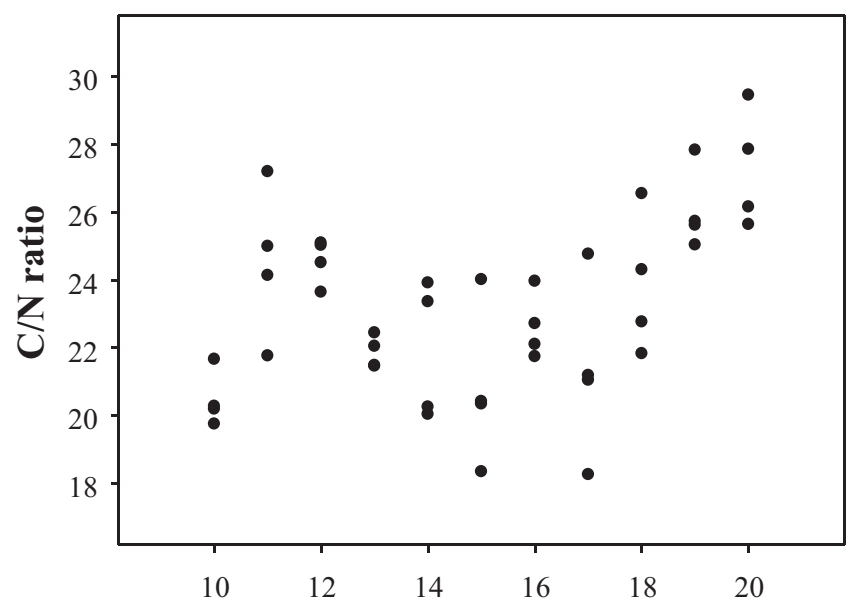

Plant age (Time after deflasking, months)

Fig. 2. The carbon/nitrogen $(\mathrm{C} / \mathrm{N})$ ratio of Phalaenopsis Sogo Yukidian 'V3' at various plant ages.

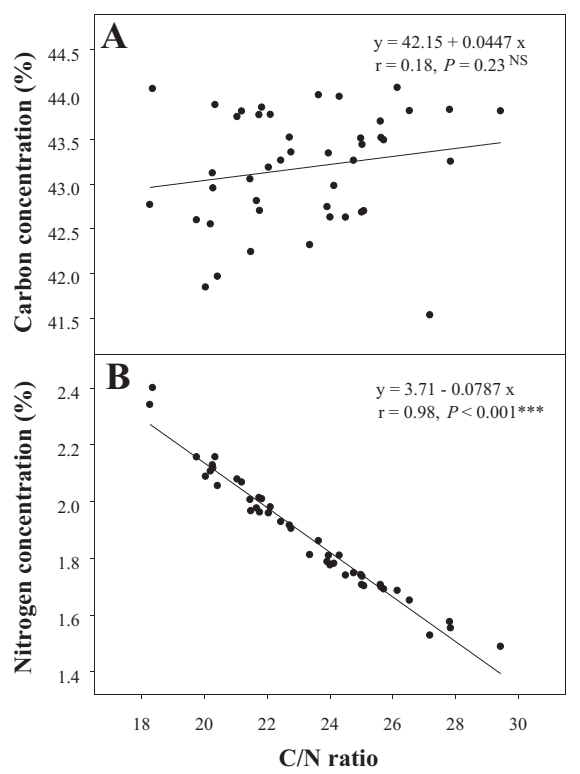

Fig. 3. The relationship between carbon/nitrogen $(\mathrm{C} / \mathrm{N})$ ratio and the concentration of carbon $(\mathbf{A})$ and nitrogen (B) of Phalaenopsis Sogo Yukidian 'V3' at various plant ages. NS, ***Not significant or significant at $P \leq 0.001$ by linear regression, respectively.

In terms of flower quality, the inflorescence length, flower-stalk width, first flower diameter, and flower count of $P$. Sogo
Yukidian 'V3' all increased as plant age increased (Table 5). Flower quality was lowest in the youngest, 10-month-old plants. The 
Table 4. Effect of plant age on flowering of Phalaenopsis Sogo Yukidian 'V3'.

\begin{tabular}{lcccc}
\hline Plant age (mo.) $)^{\mathrm{z}}$ & $\begin{array}{c}\text { Time to spiking } \\
(\mathrm{d})\end{array}$ & $\begin{array}{c}\text { Time to visible } \\
\text { bud }(\mathrm{d})\end{array}$ & $\begin{array}{c}\text { Time to first flower } \\
\text { open }(\mathrm{d})\end{array}$ & $\begin{array}{c}\text { Time to } 90 \% \text { flower } \\
\text { open }(\mathrm{d})\end{array}$ \\
\hline 10 & $35.3 \mathrm{abc}^{\mathrm{y}}$ & $82.5 \mathrm{ab}$ & $110.8 \mathrm{ab}$ & $137.5 \mathrm{ab}$ \\
11 & $33.5 \mathrm{abc}$ & $79.3 \mathrm{ab}$ & $106.5 \mathrm{ab}$ & $133.3 \mathrm{~b}$ \\
12 & $35.3 \mathrm{abc}$ & $85.3 \mathrm{ab}$ & $118.5 \mathrm{ab}$ & $149.0 \mathrm{ab}$ \\
13 & $31.0 \mathrm{abc}$ & $83.0 \mathrm{ab}$ & $115.0 \mathrm{ab}$ & $146.3 \mathrm{ab}$ \\
14 & $42.3 \mathrm{ab}$ & $85.8 \mathrm{ab}$ & $119.3 \mathrm{a}$ & $150.0 \mathrm{a}$ \\
15 & $43.5 \mathrm{a}$ & $89.8 \mathrm{ab}$ & $118.3 \mathrm{ab}$ & $152.5 \mathrm{a}$ \\
16 & $25.5 \mathrm{c}$ & $72.0 \mathrm{~b}$ & $102.5 \mathrm{~b}$ & $147.3 \mathrm{ab}$ \\
17 & $29.5 \mathrm{bc}$ & $76.8 \mathrm{ab}$ & $105.5 \mathrm{ab}$ & $141.8 \mathrm{ab}$ \\
18 & $27.0 \mathrm{c}$ & $73.5 \mathrm{ab}$ & $102.8 \mathrm{ab}$ & $139.3 \mathrm{ab}$ \\
19 & $26.8 \mathrm{c}$ & $72.8 \mathrm{ab}$ & $103.5 \mathrm{ab}$ & $138.5 \mathrm{ab}$ \\
20 & $26.3 \mathrm{c}$ & $72.0 \mathrm{~b}$ & $102.8 \mathrm{ab}$ & $149.0 \mathrm{a}$ \\
\hline${ }^{\mathrm{z}}$ Months after deflasking. & & &
\end{tabular}

${ }^{\mathrm{z}}$ Months after deflasking.

${ }^{\mathrm{y}}$ Means with different letters were significantly different by the least significant difference test at $P \leq$ $0.05 ; \mathrm{n}=4$.

increase in inflorescence length, flower-stalk width, first flower diameter, and flower count from the 10- to the 20-month-old plants were from 57.6 to $106.4 \mathrm{~cm}$, from 5.1 to $6.5 \mathrm{~mm}$, from 87 to $110 \mathrm{~mm}$, and from 6.5 to 13.3 , respectively (Table 5). Furthermore, a positive linear relationship exists between leaf $\mathrm{C} /$ $\mathrm{N}$ ratio and inflorescence length, flower-stalk width, first flower diameter, and flower number. Especially in inflorescence length $(r=$ $\left.0.40^{* *}\right)$ and flower count $\left(r=0.41^{* *}\right)$, the correlation is highly positive. These results indicated that the flower quality increased with the increase of leaf $\mathrm{C} / \mathrm{N}$ ratio (Fig. 5).

\section{Discussion}

Plant maturity affects flowering ability and flower quality. The fresh weight, dry weight, and leaf area of a white, large-flowered phalaenopsis $[P$. Mount Kaala 'Elegance' $\times(P$. Keith Shiffer $\times P$. Winter Maiden) Selfed] increased with plant age (Lee and Wang, 1997). Lin and Lee (1988) reported that rising photosynthetic efficiency and fast increase in leaf number and total leaf area can shorten the juvenile period in phalaenopsis. In addition, sufficient leaf number and nodes are the prerequisite for spiking in phalaenopsis (Sakanishi et al., 1980). Thus, nutrient accumulation in a phalaenopsis plant, which is affected by plant age, leaf number, and leaf area, should be taken into account when discussing the juvenile phase of phalaenopsis.

After forcing at $25 / 20^{\circ} \mathrm{C}$, the time needed to reach spiking in a white, large-flowered phalaenopsis decreased with increasing plant age, which means there is a negative correlation between days to spiking and total leaf area (Lee and Wang, 1997). In the current research, time to spiking in $P$. Sogo Lotte 'F2510' decreased as plant age increased (Table 1). Juvenile phase is one of the affecting factors in flowering. Plants of Cineraria 'Cindy Blue' can sense low temperature and start flower differentiation when plants have six to seven leaves. Moreover, the diameter of shoot tips is between 0.15 and $0.18 \mathrm{~mm}$ when plants transform from the juvenile to mature stage. However, cineraria seedlings under $56 \mathrm{~d}$ of age that have fewer than 8 leaves with shoot tip diameters under 0.15 $\mathrm{mm}$ cannot react to low temperature to start flower differentiation after 3 weeks of lowtemperature treatment. This indicates that these plants have not passed through the juvenile phase completely (Yeh and Atherton, 1997). Yoneda et al. (1991) compared the flowering characteristics of young (3 years old), large, white-flowered phalaenopsis with mature plants (6 years old). After forcing at 22 or $23^{\circ} \mathrm{C}$, there was no difference in days to spiking between young and mature plants, which was between 33 and $54 \mathrm{~d}$. Nevertheless, young phalaenopsis had not only lower flower-stalk emergence percentage but also shorter inflorescence with fewer flowers than mature plants (Yoneda et al., 1991). In this study, the 2-month-old $P$. Sogo Lotte 'F2510' plants were the youngest and had lower spiking rate and poorer flower quality (Table 2). The other plants were 3 months and older and had 100\% flower-stalk emergence, implying that these plants of the small-flowered 'F2510' had passed their juvenile phase and were able to produce quality flowers.

In this research, the 2-month-old small, purple-flowered phalaenopsis took the longest time to reach spiking, visible bud, and first flower opening (Table 1). The phenomenon may relate to the nutrient status in plants. Two months after deflasking, the young plants had only 4.1 leaves, which is fewer than the 7.3 leaves in the 7-month-old plants (data not shown). Low leaf number in the 2month-old $P$. Sogo Lotte 'F2510' led to less accumulation of photosynthates, rendering a much smaller pool of nutrients; this may account for the delayed spiking. On the other

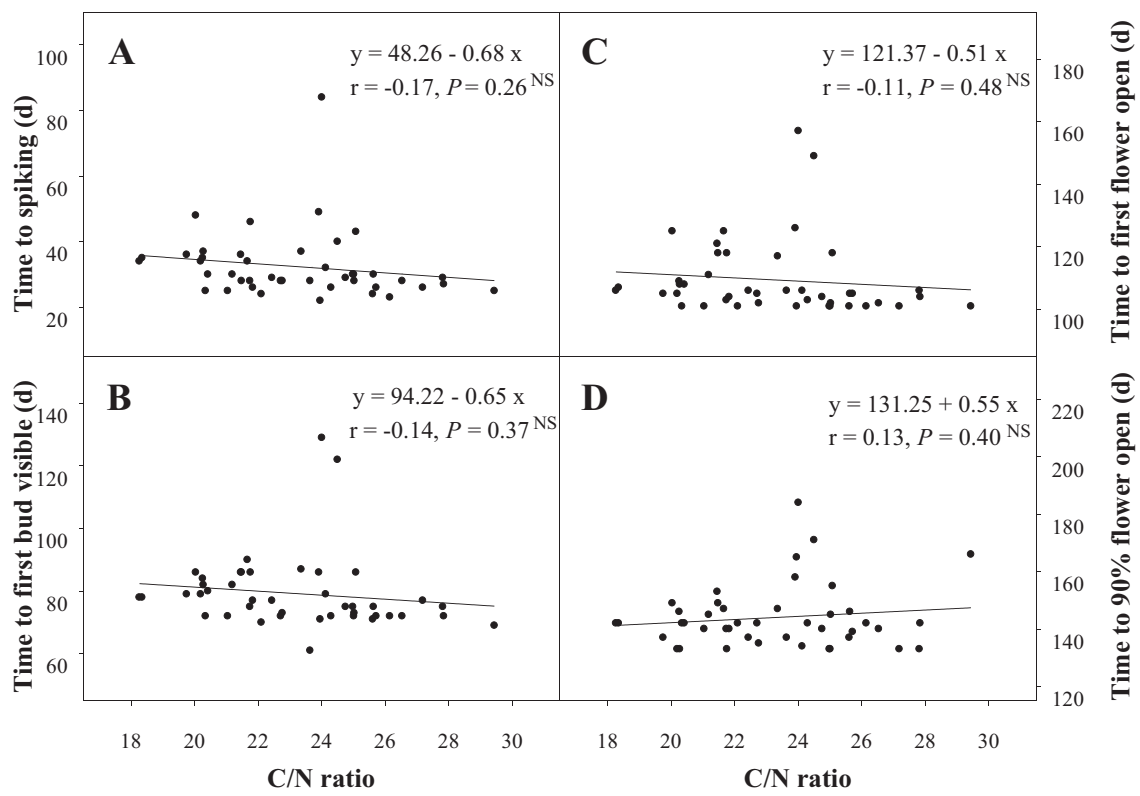

Fig. 4. The relationship between carbon/nitrogen $(\mathrm{C} / \mathrm{N})$ ratio and time to spiking $(\mathbf{A})$, time to first visible bud $(\mathbf{B})$, time to first flower open $(\mathbf{C})$, and time to $90 \%$ flower open (D) of Phalaenopsis Sogo Yukidian 'V3' at various plant ages. NS = nonsignificant by linear regression. 


\begin{tabular}{|c|c|c|c|c|c|}
\hline Plant age $(\mathrm{mo} .)^{\mathrm{z}}$ & Flower-stalk emergence (\%) & Inflorescence length $(\mathrm{cm})$ & Flower-stalk width (mm) & First flower diam $(\mathrm{mm})$ & Flower count (no.) \\
\hline 10 & $100 \%$ & $57.6 \mathrm{~g}^{\mathrm{y}}$ & $5.1 \mathrm{f}$ & $87 \mathrm{c}$ & $6.5 \mathrm{e}$ \\
\hline 12 & $100 \%$ & $63.5 \mathrm{~g}$ & $5.6 \mathrm{ef}$ & $105 \mathrm{ab}$ & $7.8 \mathrm{cde}$ \\
\hline 14 & $100 \%$ & $77.2 \mathrm{de}$ & $6.2 \mathrm{bcd}$ & $91 \mathrm{c}$ & $9.3 \mathrm{bcd}$ \\
\hline 15 & $100 \%$ & $86.1 \mathrm{bcd}$ & $6.0 \mathrm{cde}$ & $108 \mathrm{ab}$ & $9.8 \mathrm{bc}$ \\
\hline 16 & $100 \%$ & $93.0 \mathrm{bc}$ & $6.7 \mathrm{ab}$ & $116 \mathrm{a}$ & $10.5 \mathrm{~b}$ \\
\hline 17 & $100 \%$ & $84.5 \mathrm{~cd}$ & $5.8 \mathrm{de}$ & $106 \mathrm{ab}$ & $9.8 \mathrm{bc}$ \\
\hline 20 & $100 \%$ & $106.4 \mathrm{a}$ & $6.5 \mathrm{abc}$ & $110 \mathrm{ab}$ & $13.3 \mathrm{a}$ \\
\hline
\end{tabular}

${ }^{\mathrm{z}}$ Months after deflasking.

${ }^{\mathrm{y}}$ Means with different letters were significantly different by the least significant difference test at $P \leq 0.05 ; \mathrm{n}=4$.

hand, there is no statistical difference in time to reach $90 \%$ flowering between the 2 month-old plants and others because the 2month-old plants produced fewer flowers (4.6) than others, such as 9.4 flowers in the 7month-old plants (Table 2). Therefore, even though the 2-month-old $P$. Sogo Lotte ' $F 2510$ ' first flowered $\approx 20 \mathrm{~d}$ later than the others, it reached $90 \%$ flower opening earlier than plants of more advanced ages (Table 1).

Lin and Chang (2017) investigated C/N ratio and carbon and nitrogen concentration on a large, white-flowered phalaenopsis $(P$. Sogo Yukidian 'V3') at four growth stages: tissuecultured plantlet, small plant, medium plant, and large plant. They showed that nitrogen concentration declined as plant grew and $\mathrm{C} / \mathrm{N}$ ratio, which was influenced by nitrogen concentration, rose with the growth of plants. In the 2- to 5-month-old small, purple-flowered phalaenopsis, $\mathrm{C} / \mathrm{N}$ ratio of the second leaf increased with plant age as plants getting matured (Fig. 1) due to a trend of decreasing $\mathrm{N}$ (data not shown). The $\mathrm{C} / \mathrm{N}$ ratio in the second acropetal leaf decreased to 21.1 and 21.9 in 6and 7-month-old plants (Fig. 1), respectively, because of a high $\mathrm{N}$ level, which was $2.00 \%$ and $1.95 \%$, respectively, compared with that of $1.69 \%$ in the 5-month-old plants (data not shown). A possible reason is that during cultivation, as plant size increased, growers also increased fertilizer concentration; thus, plants absorbed more nitrogen fertilizer. Susilo et al. (2013) reported that vigorously growing new leaves were the major sink of $\mathrm{N}$ in the large white-flowered phalaenopsis ' $\mathrm{V} 3$ ' during vegetative growth. In this study, the second leaf of 6-month-old 'F2510' plants was relatively young and growing, which could be considered a strong $\mathrm{N}$ sink. Therefore, when fertilizer was applied at a higher rate, more nutrients entered the second leaf to support its growth. As a result, the second leaf might have acquired more $\mathrm{N}$, which led to an increase of $\mathrm{N}$ concentration and a decrease in $\mathrm{C} / \mathrm{N}$ ratio.

The relationship among plant maturity, $C /$ $N$ ratio, and flower quality. Many factors can influence phalaenopsis flowering, including temperature, light, and juvenile phase (Lee and Lin, 1987). Besides these factors, plant nutrient status is another important factor. Kubota and Yoneda (1993) stated that the reason for phalaenopsis not being able to spike and flower in a low-light-intensity

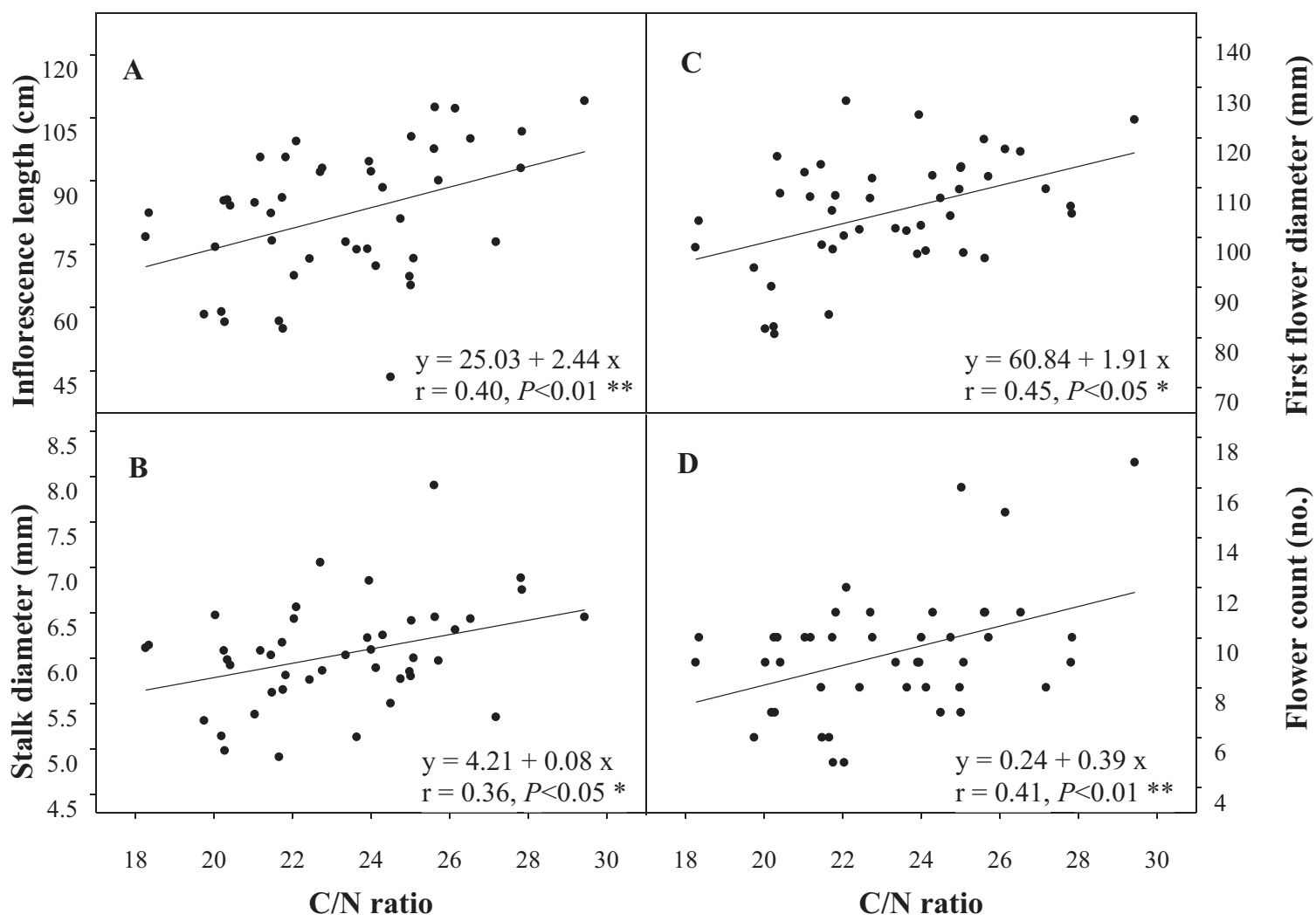

Fig. 5. The relationship between carbon/nitrogen $(\mathrm{C} / \mathrm{N})$ ratio and flowering quality of Phalaenopsis Sogo Yukidian 'V3' at various plant ages. (A) Inflorescence length, (B) stalk diameter, (C) first flower diameter, and (D) flower count. ${ }^{*},{ }^{*}$ Significant at $P \leq 0.05$ or 0.01 by linear regression, respectively. 
environment is the low levels of reducing sugar concentration and accumulation of ethanol-soluble nitrogenous compounds in plants. Their results could suggest that low $\mathrm{C} /$ $\mathrm{N}$ ratio might suppress spiking and therefore flowering, and high $\mathrm{C} / \mathrm{N}$ ratio could boost spiking and flowering in phalaenopsis.

In the white, large-flowered phalaenopsis 'V3', generally speaking, $\mathrm{C} / \mathrm{N}$ ratio increased with plant age (Fig. 2). For the 12- to 17month-old plants, $\mathrm{C} / \mathrm{N}$ ratio was between 20.8 and 24.6, and for the 18- to 20-monthold phalaenopsis, which were completely mature, $\mathrm{C} / \mathrm{N}$ ratio was from 23.9 to 27.3 (Table 3). Plant $\mathrm{C} / \mathrm{N}$ ratio is the ratio of carbon concentration to $\mathrm{N}$ concentration; therefore, any change in carbon or $\mathrm{N}$ concentration affects the value of $\mathrm{C} / \mathrm{N}$ ratio. The result from the regression analysis showed that there is a highly negative correlation between $\mathrm{C} / \mathrm{N}$ ratio and $\mathrm{N}$ concentration (Fig. 3). In general, $\mathrm{N}$ concentration declined as plant age increased. The $\mathrm{N}$ concentration of 12- to 17-month-old $P$. Sogo Yukidian 'V3' was between $1.75 \%$ and $2.10 \%$, and this dropped to between $1.61 \%$ and $1.84 \%$ in 18 to 20-month-old plants (Table 3). The carbon concentration was relatively stable, between $42.5 \%$ and $43.8 \%$ (Table 3). Decrease in N concentration in leaf is the major reason for the increase of $\mathrm{C} / \mathrm{N}$ ratio with plant age.

Plants 10 months and older reacted to forcing conditions and produced inflorescences, which implies that their juvenile stage was over and all the plants had the ability to flower fully (Table 5). There is no correlation between $\mathrm{C} / \mathrm{N}$ ratio and days to spiking $(P=$ $0.26)$, visible bud $(P=0.37)$, first flower open $(P=0.48)$, or $90 \%$ flower opening $(P=0.40)$ (Fig. 4). This result indicates that $\mathrm{C} / \mathrm{N}$ ratio has less impact on spiking and flowering time in $P$. Sogo Yukidian 'V3' once the plant has passed its juvenile phase. Paradiso and Pascale (2014) claimed that plant size might have an effect on spiking and first flower opening time. In their research, large plants were the plants with five leaves and small plants had only three leaves. However, after forcing, the large plants spiked and flowered only $5 \mathrm{~d}$ earlier than the small plants.

$\mathrm{C} / \mathrm{N}$ ratio is positively correlated with flower quality parameters such as inflorescence length $\left(r=0.40^{* *}\right)$, flower-stalk diameter $\left(r=0.36^{*}\right)$, first flower diameter $(r=$ $\left.0.45^{*}\right)$, and flower count $\left(r=0.41^{* *}\right)$ (Fig. 5). Paradiso and Pascale (2014) pointed out that the size of phalaenopsis plants can affect flower quality. Compared with small plants, large plants have longer inflorescence, thicker flower stalk, and more flowers. All these characteristics indicate that large phalaenopsis plants improve flower quality. Nonetheless, in their research, leaf number was used to determine plant size, but until now, there is no scientific method for representing plant age of phalaenopsis. Lin and Chang (2017) used phalaenopsis at various growth stages to investigate the change in $\mathrm{C} / \mathrm{N}$ ratio. They found that $\mathrm{C} / \mathrm{N}$ ratio increases with cultivation time, which demonstrates the possibility that using $\mathrm{C} / \mathrm{N}$ ratio for judging plant maturity in phalaenopsis. In our second experiment, we used $10-$ to 20-month-old phalaenopsis as materials. The current research covered a more detailed range of plant ages, and the range of plant $\mathrm{C} / \mathrm{N}$ ratio was also broader (Table 3 ). When comparing the flower quality between medium (10- to 11-month-old), large (12- to 17-month-old), and extra-large (18- to 20-month-old) plants, we noticed that medium plants had the worst flower quality. In contrast, the extra-large phalaenopsis ' $\mathrm{V} 3$ ' had a higher $\mathrm{C} / \mathrm{N}$ ratio (23.9 to 27.3) than the medium and large plants. Furthermore, these plants also performed better than the medium and large ones (Tables 3 and 5). To summarize, $\mathrm{C} / \mathrm{N}$ ratio and flower quality are positively correlated in phalaenopsis. When phalaenopsis plants have higher $\mathrm{C} / \mathrm{N}$ ratios, they will have better performance with regard to flower quality characteristics such as inflorescence length, flower-stalk thickness, first flower diameter, and flower count.

\section{Literature Cited}

Corbesier, L., G. Bernier, and C. Périlleux. 2002. $\mathrm{C}: \mathrm{N}$ ratio increases in the phloem sap during floral transition of the long-day plants Sinapis alba and Arabidopsis thaliana. Plant Cell Physiol. 43:684-688, https://doi.org/10.1093/pcp/pcf071.

Hew, C.S. and J.W.H. Yong. 2004. Control of flowering, p. 168-197. In: C.S. Hew and J.W.H. Yong (eds.). The physiology of tropical orchids in relation to the industry. World Scientific, Singapore, https://doi.org/10.1142/9789812567215_ 0006.

Kubota, S. and K. Yoneda. 1993. Effects of light intensity on developmental and nutritional status of Phalaenopsis. J. Jpn. Soc. Hort. Sci. 62:173-179, https://doi.org/10.2503/jjshs.62.173.

Lee, N. and G.M. Lin. 1987. Controlling and flowering of Phalaenopsis. Proceedings of 1st symposium on forcing culture of horticultural crops. p. 27-44. Taichung District Agricultural Research and Extension Station, Taichung, Taiwan.
Lee, N. 1991. Juvenility in phalaenopsis. Proceedings of 2nd symposium on forcing culture of horticultural crops. p. 77-86. Taichung District Agricultural Research and Extension Station, Taichung, Taiwan.

Lee, N. and M.C. Wang. 1997. Changes in mineral composition and carbohydrate contents from juvenile to mature phase in white-flowered Phaleanopsis plants. J. Chinese Soc. Hort. Sci. 43:295-305, https://doi.org/10.6964/ JCSHS.199712.0295.

Lin, G.M. and N. Lee. 1988. Leaf area estimation and the effect of temperature on the growth of Phalaenopsis leaves. J. Chinese Soc. Hort. Sci. 34:73-80, https://doi.org/10.6964/JCSHS.198803.0073.

Lin, J.A. 2017. Effects of carbon and nitrogen concentrations and $\mathrm{C} / \mathrm{N}$ ratio on flowering of phalaenopsis and nobile-type dendrobium. Natl. Taiwan Univ. Taipei, Taiwan, MS thesis, https:// doi.org/10.6342/NTU201703200.

Lin, J.A. and Y.C.A. Chang. 2017. Partitioning of nitrogen and carbon in Phalaenopsis and their progressive changes with plant growth and development. HortScience 52:1530-1536, https:// doi.org/10.21273/hortsci12484-17.

Mandal, D., A. Sarkar, and B. Ghosh. 2014. Induction of flowering by use of chemicals and cincturing in 'Bombai' litchi. Acta Hort. 1029:265-271, https://doi.org/10.17660/Acta Hortic.2014.1029.32.

Paradiso, R. and S.D. Pascale. 2014. Effects of plant size, temperature, and light intensity on flowering of Phalaenopsis hybrids in Mediterranean greenhouses. Scientific World J. 2014:1-9, https://doi.org/10.1155/2014/420807.

Sakanishi, Y., H. Imanishi, and G. Ishida. 1980. Effect of temperature on growth and flowering of Phalaenopsis amabilis. Bul. Univ. Osaka Prefecture. 32:1-9.

Schwabe, W. 1975. Applied aspects of juvenility and some theoretical considerations. Symp. Juvenility in Woody Perennials. 56:45-56, https://doi.org/10.17660/ActaHortic.1976.56.3.

Susilo, H., Y.C. Peng, S.C. Lee, Y.C. Chen, and Y.C.A. Chang. 2013. The uptake and partitioning of nitrogen in Phalaenopsis Sogo Yukidian 'V3' as shown by ${ }^{15} \mathrm{~N}$ as a tracer. J. Amer. Soc. Hort. Sci. 138:229-237, https://doi.org/10.21273/ jashs.138.3.229.

Wangsin, N. and T. Pankasemsuk. 2005. Effect of potassium chlorate on flowering, total nitrogen, total nonstructural carbohydrate, $\mathrm{C} /$ $\mathrm{N}$ ratio, and contents of cytokinin-like and gibberellin-like substances in stem apex 'Do' longan. Acta Hort. 665:255-258, https://doi. org/10.17660/ActaHortic.2005.665.29.

Yeh, D.M. and J.G. Atherton. 1997. Manipulation of flowering in cineraria. II. Juvenility. J. Hort. Sci. 72:55-66, https://doi.org/10.1080/ 14620316.1997.11515490.

Yoneda, K., H. Momose, and S. Kubota. 1991 Effects of daylength and temperature on flowering in juvenile and adult Phalaenopsis plants. J. Jpn. Soc. Hort. Sci. 60:651-657, https://doi. org/10.2503/jjshs.60.651. 